LA WRENCE LIWEAMCAE NATIONAL LABOAATOAY

Rapid Qualitative Risk Assessment for Contaminant Leakage from Coal Seams During Underground Coal Gasification and $\mathrm{CO}_{2}$

Injection

Samuel J. Friedmann

Lawrence Livermore National Laboratory Livermore, $C A$

July 2004 


\section{Disclaimer}

This document was prepared as an account of work sponsored by an agency of the United States Government. Neither the United States Government nor the University of California nor any of their employees, makes any warranty, express or implied, or assumes any legal liability or responsibility for the accuracy, completeness, or usefulness of any information, apparatus, product, or process disclosed, or represents that its use would not infringe privately owned rights. Reference herein to any specific commercial product, process, or service by trade name, trademark, manufacturer, or otherwise, does not necessarily constitute or imply its endorsement, recommendation, or favoring by the United States Government or the University of California. The views and opinions of authors expressed herein do not necessarily state or reflect those of the United States Government or the University of California, and shall not be used for advertising or product endorsement purposes.

This work was performed under the auspices of the U.S. Department of Energy by the University of California, Lawrence Livermore National Laboratory under Contract No. W-7405-Eng-48. 


\title{
Rapid qualitative risk assessment for contaminant leakage from coal seams during underground coal gasification and $\mathrm{CO}_{2}$ injection
}

\author{
S. Julio Friedmann \\ Energy \& Environmental Directorate
}

\section{Summary}

One of the major risks associated with underground coal gasification is contamination of local aquifers with a variety of toxic compounds. It is likely that the rate, volume, extent, and concentrations of contaminant plumes will depend on the local permeability field near the point of gasification. This field depends heavily on the geological history of stratigraphic deposition and the specifics of stratigraphic succession. Some coals are thick and isolated, whereas others are thinner and more regionally expressed. Some coals are overlain by impermeable units, such as marine or lacustrine shales, whereas others are overlain by permeable zones associated with deltaic or fluvial successions. Rapid stratigraphic characterization of the succession provides first order information as to the general risk of contaminant escape, which provides a means of ranking coal contaminant risks by their depositional context. This risk categorization could also be used for ranking the relative risk of $\mathrm{CO}_{2}$ escape from injected coal seams. Further work is needed to verify accuracy and provide some quantification of risks.

\section{Introduction}

Coal seams serve increasingly as the target for subsurface applications, including coal-bed methane (CBM), underground gasification, and $\mathrm{CO}_{2}$ injection and storage. As environmental concerns mount regarding these applications, questions mount regarding coal bed geometry, continuity, and connection to local and regional aquifers. These terms affect the magnitude and risk associated with leakage and contamination away from coal seams, and will underlie health, safety, environmental, and regulatory concerns in projects applied to subsurface coals.

Stratigraphic and sedimentological tools and methods exist that can help to define or characterize the risk associated with subsurface coaly environments. Application of these tools to questions of underground coal gasification and the associated contamination risks can be used to high-grade potential projects sites and discount others. This paper presents a qualitative guide to application of these tools and methods. Future research, based in outcrop, core, and well-logs, may be needed to provide more quantitative risk estimates.

\section{Stratigraphic successions and relative base level changes}

As sedimentary basins accumulate strata, changes in tectonics, climate, eustatic sea level, and sediment supply force changes depositional environments (e.g. Mitchum et al. 1977; Jervey 1988). These stratigraphic forcing functions first and foremost alter base level, defined as the level below which erosion cannot take place (Davis 1902; Twenhofel 1939; Schumm 1993). Base level determines the location and style of sedimentary deposition, and in most sedimentary systems is equivalent to sea level. Base level changes through geologic time, driven by any stratigraphic forcing, strongly affect the style and distribution of sedimentary types. Stratigraphic forcing also affects accommodation space, defined as the space available to deposit sediments (e.g. Jervey 1988; Van Wagoner et al 1990). For example is subsidence increases or absolute sea level rises, there is an increase in accommodation space.

A useful predictive, description conceptual framework for base level and accommodation changes is sequence stratigraphy (e.g. Mitchum et al 1977; Van Wagner 1990). Increases or decreases in 
accommodation or base level cause a predictable migration of depositional systems that are bounded by important surface, including flooding surfaces or unconformities. Such surfaces can be used to define positions in the context of relative base level changes, and are often grouped into lowstand, transgressive, and highstand systems tracts based on internal characteristics and overall stacking patterns. By examining the stacking patters of these stratal packages bounded by key surfaces, one can predict the lateral and vertical character of sedimentary units away from data points such as wells, seismic lines, or outcrops (Van Wagoner et al. 1990).

\section{Coal depositional environments}

Coals generally accumulate in mires, initially as accumulations of peat (e.g. Moore 1989). This requires a high water table and low rate of clastic influx (McCabe 1984, Courel 1989; Allen 1990; McCabe 1991). Location, volume, quality, and extent of coal seams reflect changes in accommodation and peat accumulation rates (e.g., Hamilton \& Tadros, 1994; Bohacs \& Suter, 1997). Other linked depositional systems, such as deltas, shorefaces, tidal systems, rivers, and coastal plains, also respond to this stratigraphic forcing (Jervey 1988, Van Wagoner et al. 1990).

Coals can be deposited in three major environmental contexts: regional (e.g., during a basin-wide disruption of siliciclastic influx), during nodal avulsion of channels, and local (within abandoned or between active channels). Figure 1 illustrates these different settings. As one can see, some of these coals have a higher likelihood of connection to permeable and porous units as a function of their depositional context.

Figure 2 shows how these different coal-related environments move through space over geological time during one cycle of baselevel fluctuations. Although these are marine systems, the same methodology applies to base-level changes in lacustrine coal systems as well (e.g., Hamilton \& Tadros, 1994). Increases in relative base level produce transgressions (e.g., transgressive systems tract) and a backstepping of the depositional systems. In some circumstances, this results in coals being buried in marine or lacustrine shales, which have a low permeability. Relative base level falls cause progradation of sedimentary systems and regression, wherein coals may be succeeded by river systems, erosion, and exposure (e.g.,

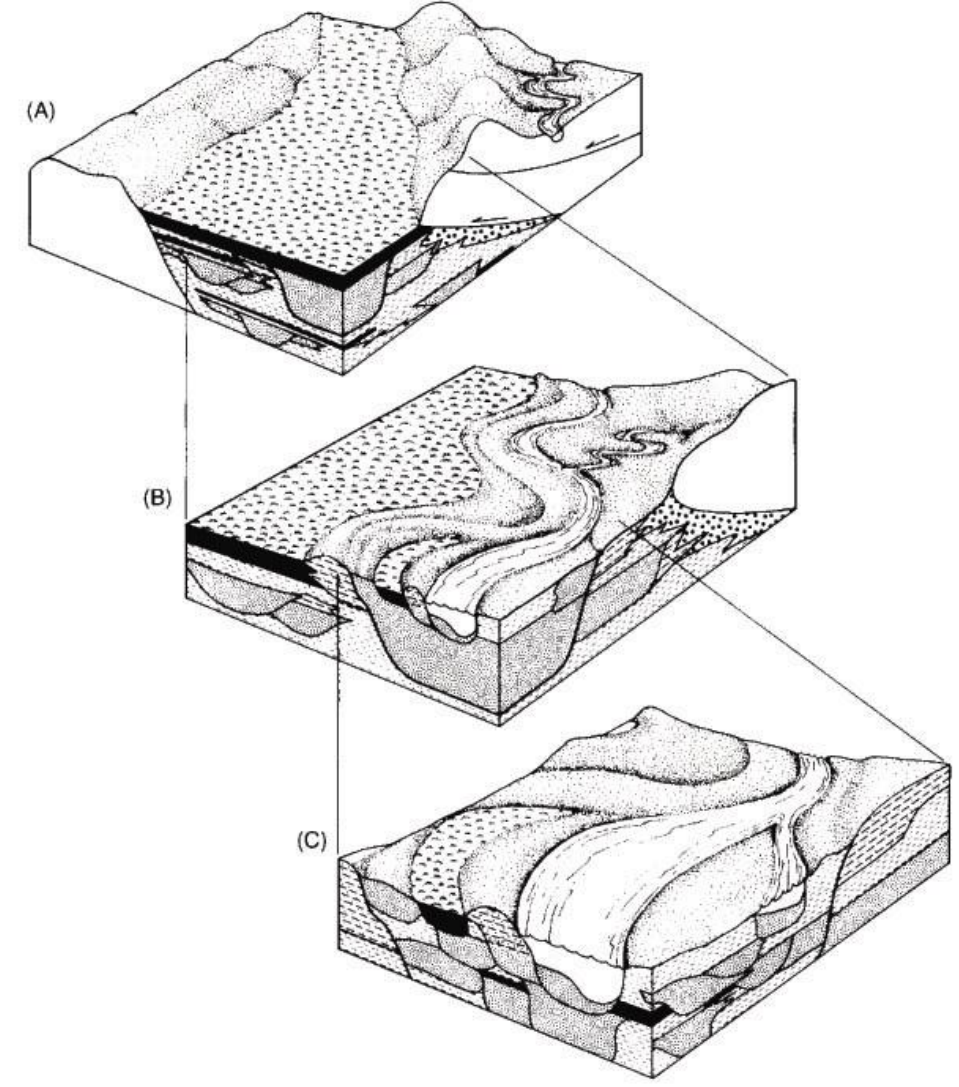

Figure 1: Schematic block diagrams showing the general habitat of coal occurrence (A) basinal, (B) sub-regional, and (C) local. From Hamilton \& Tadros (1994) 
Dalyrymple et al 1992). These changes also affect the thickness and lateral extent of coals (Bohacs and Suter, 1997).

\section{Coal containment and stratigraphic successions}

As stratigraphic forces alter the lateral and vertical distribution of strata, they directly affect the permeability field surrounding coals. They will affect the lithology immediately surrounding the coals, e.g., whether a coal is surrounded by low-permeability coastal-plain mudstone or by fluvial channels filled with permeable sandstone. Stratigraphic forcing also affects the vertical evolution of coaly units (see above), which impacts the likelihood of high permeability zones overlying target coals. Such zones may be aquifers that serve or may serve as groundwater sources for various applications (e.g., agriculture).

The predictive framework supplied by sequence stratigraphy provides a context for observations of coal targets. Bohacs \& Suter (1997) provide one model of this approach, presenting a six-tiered categorization of coal body continuity and thickness as a function of stratigraphic position (Figure 3). In the parlance of nonlinear dynamics, these changes from one category to the next occur as sedimentary systems move through a multi-dimensional phase space bounded by accommodation space, base-level position, and peat accumulation rate.
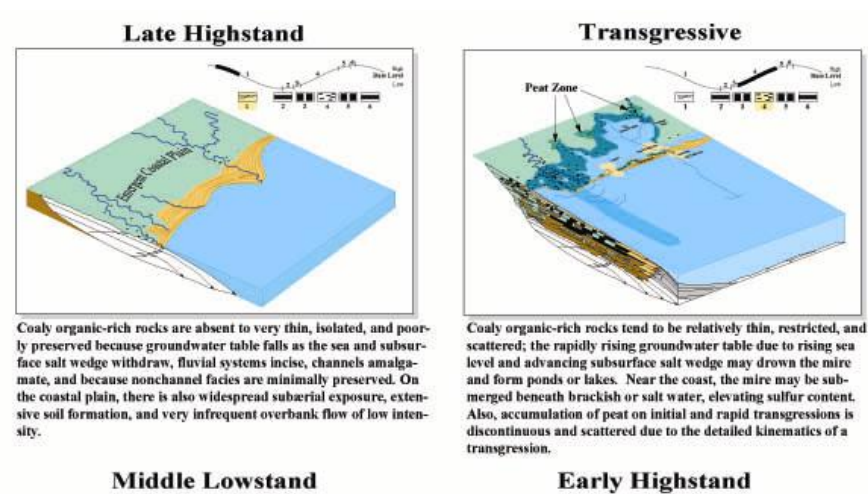
scattered; the rapidly rising groundw uter table due to rising vea and form ponds or lakes. Near the coast, the mire may be submerged beneath brackish or salt water, elevating sulfur content Also, accumulation of peat on initial and rapid transgressions is
discontinuous and scattered due to the detailed kinematics of a
transeression.

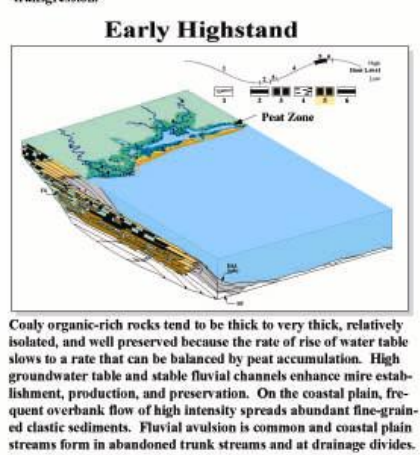

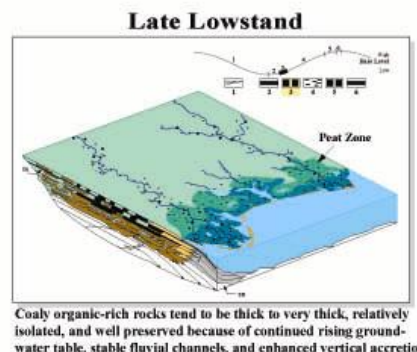
isolated, and well preserved because of continued rising ground
water table, stable fluviul water table, stable fluvial channels, af
and preservation of overbank facies:

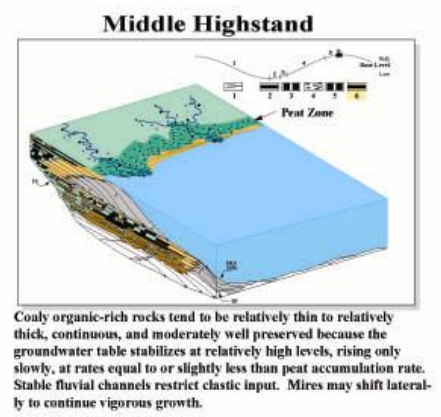

Figure 2. Block diagrams showing the distribution of depositional environments and vertical stratigraphic successions associated with one base-level cycle. From Bohacs \& Suter (1997).

Importantly, these predictions can be made based on sparse or irregularly spaced data sets, including neighboring outcrops, individual well-logs, or limited cores from neighboring wells. This allows the trained geologist to determine whether the target coal is category 3 or 5 , despite similar composition and thickness. 

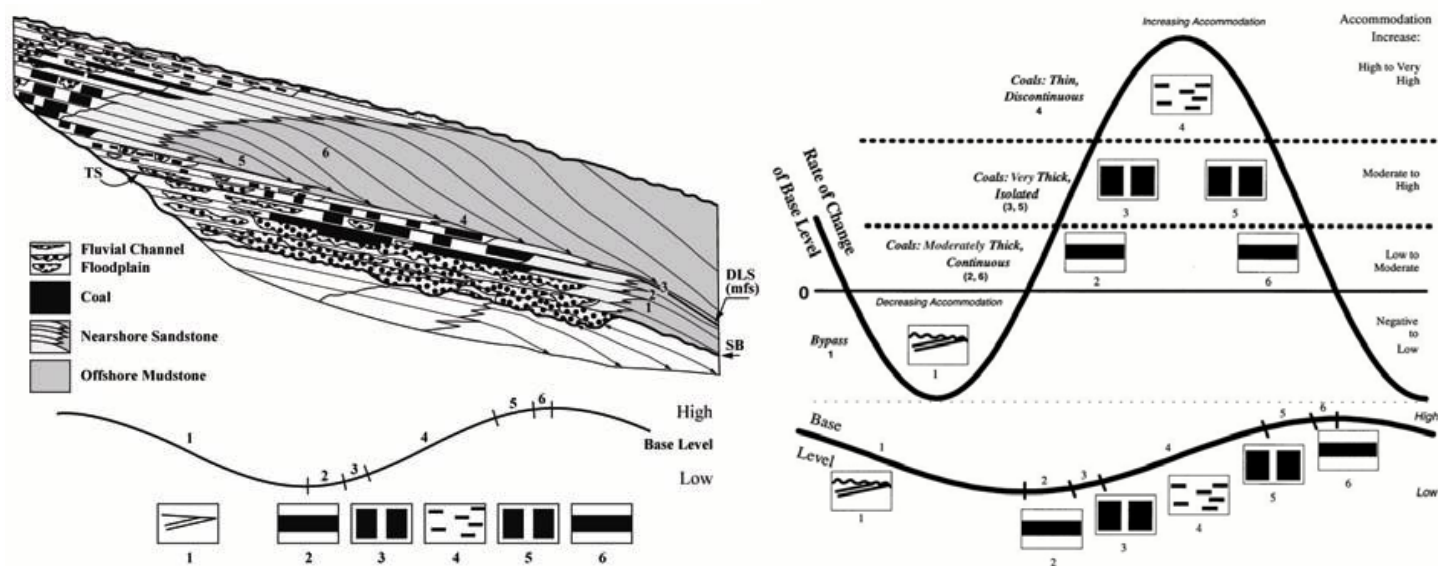

Figure 2: Schematic representation of accommodation cycles and distribution and character of associated coal deposits. (Left) Schematic drawing of one depositional sequence through an accommodation cycle, showing the general distribution of coaly units (black) and their associated facies. (Right) Associated cycle of base-level change. The six category numbers underlie the risk matrix below. From Bohacs \& Suter (1997)

\section{Risk matrix}

Using these basic concepts, it is possible to derive a crude matrix for assessing the overall permeability field surrounding a target coal. This flows from two assessments: the degree of lateral connection of the coal seam, and the character of units overlying the coals (Table 1). High isolation is preferable, as this reduces the risk of later contaminant flow into adjacent aquifers. Shale prone

Table 1: Relative Contamination Risk Matrix

\begin{tabular}{|c|c|c|c|}
\hline $\begin{array}{c}\text { Stratigraphic } \\
\text { Category }\end{array}$ & $\begin{array}{c}\text { Lateral } \\
\text { Isolation }\end{array}$ & $\begin{array}{c}\text { Overyling Unit } \\
\text { Character }\end{array}$ & $\begin{array}{c}\text { Relative Risk } \\
\text { of Leakage }\end{array}$ \\
\hline 1 & Low & Sand prone & High \\
\hline 2 & Low & Shale prone & Moderate \\
\hline 3 & High & Shale prone & Low \\
\hline 4 & Moderate & Shale prone & Moderate \\
\hline 5 & Moderate & Sand prone & High \\
\hline 6 & Low & Sand prone & High \\
\hline
\end{tabular}

intervals overlying coal seams are similarly preferable. Convolving these two aspects produces a relative ranking. This ranking can be used as a crude screening tool to high-grade potential project sites. This step should only serve as an early step, and be followed by a more rigorous deterministic or probabilistic approach.

\section{Case studies: Wyoming and Utah}

Three examples of this approach are provided below, all from the Cretaceous of the western Great Basin. These are meant to illustrate a relative ranking methodology, and should be able to be applied in the overwhelming majority of potential cases.

\section{$\underline{\text { Rock Springs Uplift }}$}

The first example from south central Wyoming involved Campanian (late Cretaceous) units of the Brooks/McCourt interval (Hendricks, 1981; Levin 1981; Beauboeuf et al 1995). Major coal seams include the \#1 and \#3 coals, although there are many coal units of varying thickness and quality distributed through the section (Figure 4). Some of these coals are deposited within fluvial channels, whereas others represent widespread mires in a coastal plain environment.

The coals below the \#1 seam would fall into category 3 (low risk) and are capped by a thick package of marine shales. In contrast, the coals above the \#3 seam would fall into category 5 , and are capped by a thick fluvial sandstone. A simple examination of the physical rock properties does not reveal this 
fact - only the recognition of the stratigraphic architecture of the whole succession provides this insight.

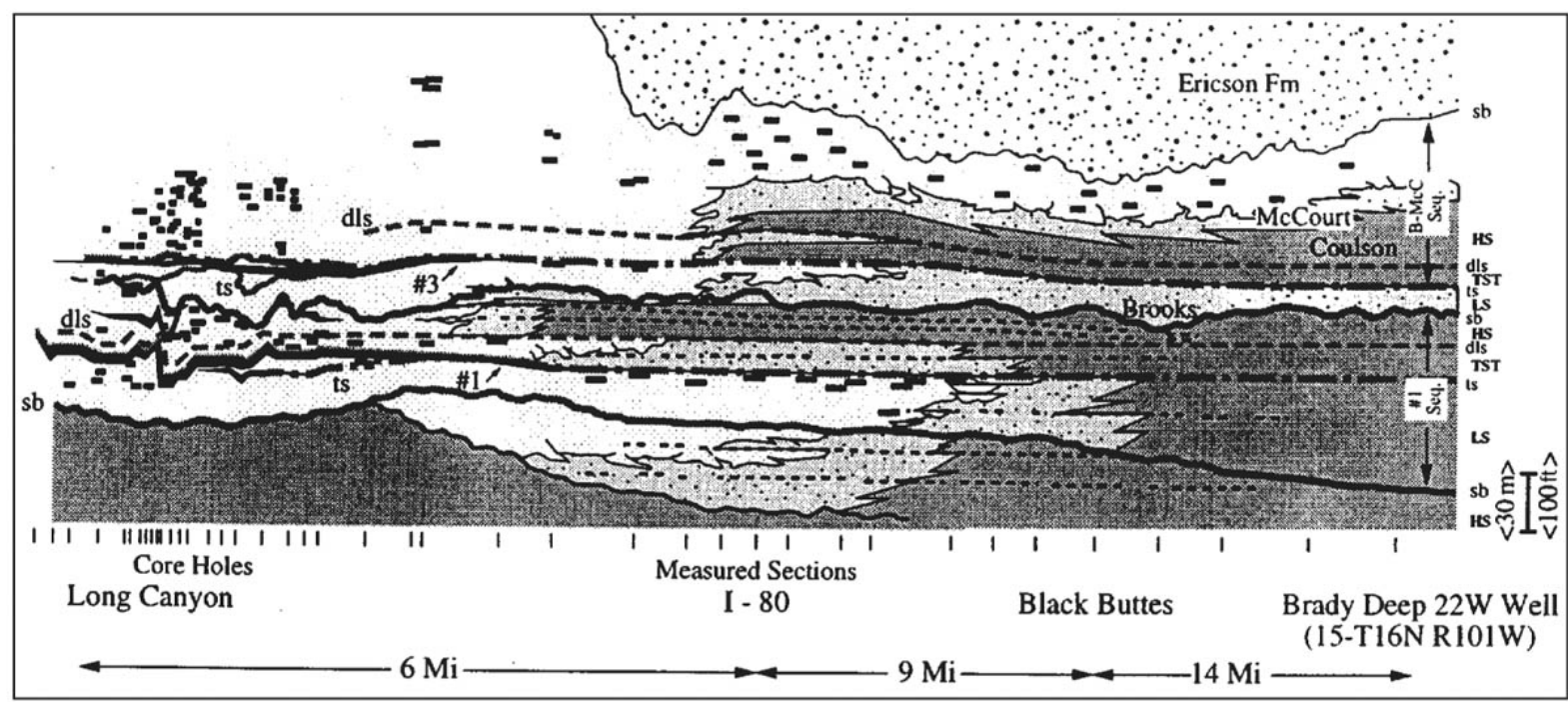

Figure 4. Cross-section of the Brooks-McCourt Sequences within the Rock Springs uplift, S. Wyoming. Note abundant coals (black) within the succession. The isolated coals beneath the \#1 seam and its correlative flooding surface present the lowest risk for leakage into neighboring porous, permeable units. From Bohacs \& Suter (1997).

Roughly 400 m up-section, the coals within the Almond Fm. are also category 3 coals, but they are even better expressed, thicker, more isolated, and capped by the thick Lewis Shale (Van Wagoner et al. 1990). Thus, within the Rock Springs uplift there are two regionally disposed high quality, lo risk intervals to prospect for underground gasification. However, there are a great many more coals available, they would all generally be more risky due to their proximity to other porous and permeable units (e.g., the Erickson Fm.).

\section{The Ferron Sandstone coal succession}

The Ferron sandstone member of the Mancos Shale accumulated during the Turonian (early Cretaceous) in eastern Utah (e.g., Cotter 1981). The Ferron is a sandstone wedge protruding far into the Mancos Shale, and as such most of the coals probably represent a low to moderate risk (Ryer
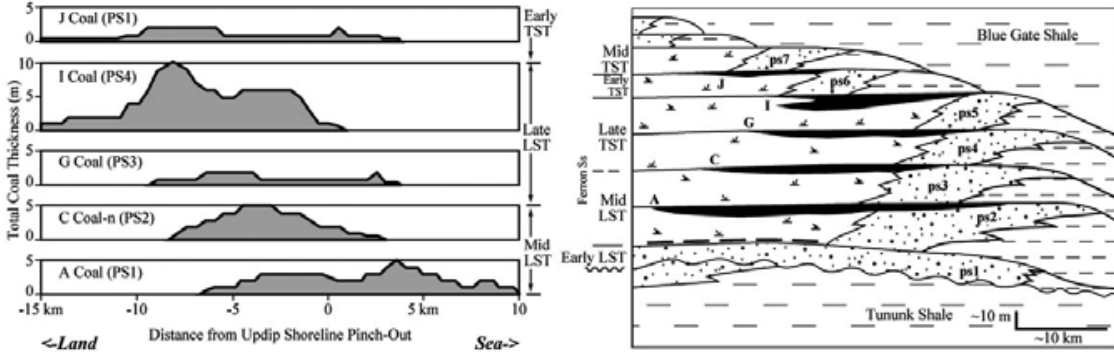

Figure 5. Thickness, vertical, and lateral distribution of the five main coal seams within the Ferron Sandstone member, Mancos Shale Fm., Emery coalfield. From Bohacs \& Suter (1997)
$1981 ; 1984)$. In the Emery coal field, five major coal seams stack within an aggradational to retrogradational set. Of these, the I and $\mathrm{J}$ coals would be the lowest risk, with the I coal providing both low risk and high thickness. 
The Blackhawk Formation coal succession

The Campanian (upper

Cretaceous) Blackhawk

formation comprises multiple

cycles of transgression and

regression within an overall

progradational package (Figure

6; Young 1955, Taylor \&

Lovell, 1991). The succession

bears at least a dozen major coal

seams, which are mined for

electric power generation.

Despite the great thickness,

continuity, and economic utility

of these coals, they all are

elevated in risk. The

progradational nature of the

succession places many fluvial

and deltaic sandstones above the

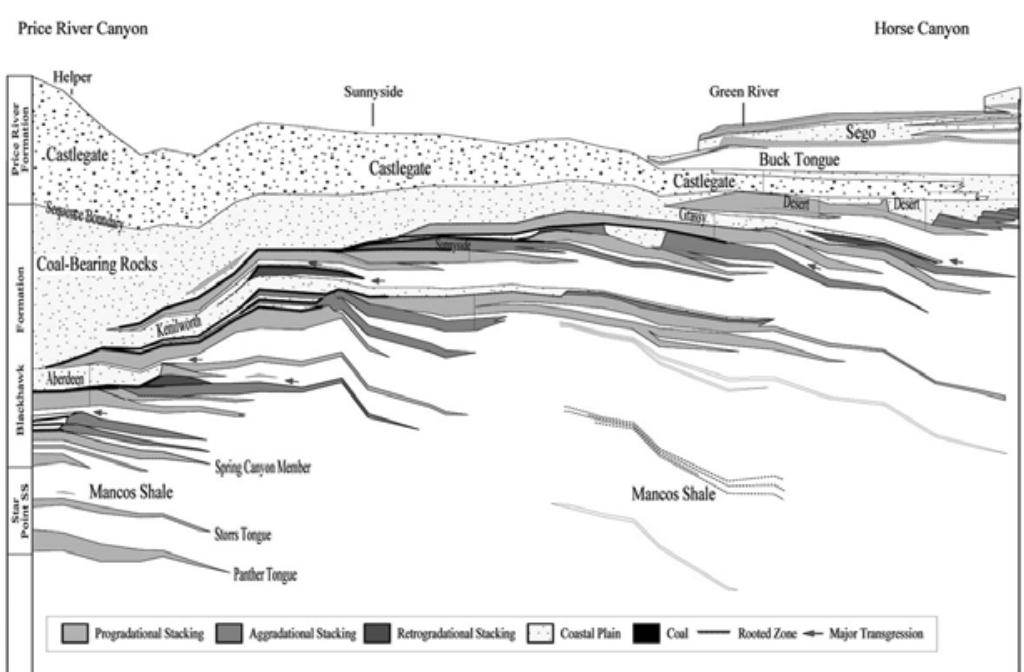

Figure 7. The Blackhawk Fm, eastern Utah, showing overall progradation and multiple coal bodies. After Young (1955).

coals across short distances laterally and verticall. These would be category 5 or 6 coals, again as seen from the context of the sedimentary succession where the coals occur.

\section{Application to carbon storage}

The risk methodology described here also applies to risks of $\mathrm{CO}_{2}$ leakage associated with carbon storage and enhanced coal-bed methane recovery (ECBM). There are examples where it looks like category three coals hold significant gas accumulations in part due to lateral and vertical stratigraphic seals (Lamarre 2002). These coals would probably be less likely to leak injected CO2 or contaminated water associated with injection, and would be less likely to be affected by potential stratigraphic or structural leakage paths (e.g., Friedmann \& Nummedal, 2003). If true, this methodology would provide a quick means for assessing the leakage risks associated with injection into unmineable coals seams.

\section{Conclusions}

- Stratigraphic forcing plays a first order role in distribution of stratal types, including coal and the rocks that bound coals.

- Simple, quick look stratigraphic techniques are capable of providing insight into the relative risk of coal leakage as a function of stratigraphic context.

- Category three coals (deposited during late lowstand and transgression) provide the overall lowest general risk of contaminant escape.

- These tools and approaches at general risking can be applied to carbon storage in unmineable coal seams. 


\section{References Cited}

Allen, JRL, 1990, The formation of coastal peat marshes under an upward tendency or relative sea level, J. of the Geol. Soc. London, 147, 743-745

Beauboeuf, RT, McLaughlin, PP, Bohacs, KM, Suter, JR, and Devlin, WJ, 1995, Sequence stratigraphy of coalbearing strata, Upper Cretaceous, Washakie basin, southwest Wyoming (abs.): AAPG Annual Meeting Abstracts, p. 7-8.

Bohacs, KM, and Sutter, J, 1997, Sequence Stratigraphic Distribution of Coaly Rocks: Fundamental Controls and Paralic Examples' AAPG Bulletin, 81, 1612- 1639

Cotter, E., 1976, The role of deltas in the evolution of Ferron Sandstone and its coals, Castle Valley, Utah: Brigham Young University Studies 22, part 3, p. 15-41.

Courel, L, 1989 Organics versus clastics: conditions necessary for peat (coal) development, Int. J of Coal Geology, 12, 193-207

Dalrymple, R. W., B. A. Zaitlin, and R. Boyd, 1992, Estuarine facies models: conceptual basis and stratigraphic implications: J.. Sedimentary Petr., 62, 1130-1146.

Davis, WM, 1902, Base-level, grade, and peneplain: J of Geology, 10, 77-111

Hamilton, DS, and Tadros, NZ, 1994, Utility of coal seams as genetic stratigraphic sequence boundaries in nonmarine basins: an example from the Gunnedah basin, Australia, AAPG Bulletin, 78, 267-286

Hendricks, M. L., 1981, Stratigraphy and tectonic history of the Mesaverde Group (Upper Cretaceous), east flank of the Rock Springs uplift, Sweetwater County, Wyoming: Ph.D. thesis, Colorado School of Mines, , $179 \mathrm{p}$

Jervey, MT, 1988 Quantitative geological modeling of clasticc depositional systems and their seismic expression, in, CK Wilgus et al. (eds), Sea-level changes: an integrated approach, SEPM Spec. Publ. 42, 183-213

Lamarre, R.A., 2002, Hydrodynamic and stratigraphic controls for a large coalbed methane accumulation in Ferron coals of east-central Utah, in SD Schwochow and V. Nuccio (eds.), Coalbed methane of North America, II: Rocky Mountain Association of Geologists, p. 71-82.

Levey, R. A., 1981, A depositional model for major coal seams in the Rock Springs Formation, Upper Cretaceous, southwest Wyoming: Ph.D. dissertation, Univ. South Carolina, Columbia, 227 p.

McCabe, PJ 1984, Depositional environments of coal and coal-bearing strata, in, RA Rahmani \& RM Flores (eds), Sedimentology of coal and coal-bearing sequences, Spec. Publ. of the Int. Assoc. of Sedimentologists, 7, 13-42

McCabe, PJ, 1991 Tectonic controls on coal accumulation, Bulletin de Societé Géologique de France, 162, 277282

Mitchell Jr., RM, Vail, PR, and Thompson III, S, 1977 Seismic stratigraphy and global changes of sea-level, part 2: the depositional sequence as a basic unit for stratigraphic analysis, in, CE Payton et al. (eds.), Seismic stratigraphy - applications to hydrocarbon exploration, AAPG Memoir 26, 53-62

Moore, PD, 1989, The ecology of peat-forming processes: a review, Int. J of Coal Sciences, 12, 89-103 
Ryer, T. A., 1981, Deltaic coals of Ferron Sandstone member of Mancos Shale; predictive model for Cretaceous coal-bearing strata of western interior: AAPG Bulletin, 65, 2323-2340.

Ryer, T. A., 1984, Transgressive-regressive cycles and the occurrence of coal in some Upper Cretaceous strata of Utah, U.S.A., in R. A. Rahmani, (ed.), Sedimentology of coal and coal-bearing sequences: Int. Assoc. of Sedimentologists Spec. Publ. 7, 217-227.

Schumm, SA, 1993, River response to baselevel changes: implications for sequence stratigraphy, J. of Geology, $101,279-294$

Taylor, DR, and Lovell, RWW, 1991, Recognition of high-frequency sequences in the Kenilworth Member of the Blackhawk Formation, Book Cliffs, Utah, in J.C VanWagoner, et al. (eds), Sequence stratigraphy applications to shelf sandstone reservoirs; outcrop to subsurface examples: Field Guide for AAPG Field Conference, Sept. 21-28, 1-9.

Twenhofel, WH, 1939, Principles of sedimentation, McGraw-Hill, New York, 610 p.

Van Wagoner, JC, Mitchum, RM, Campion, KM, and Rahmanian, VD, 1990, Siliciclastic sequence stratigraphy in well-logs, cores, and outcrops: concepts for high-resolution correlation of time and facies.

Young, RG, 1955, Sedimentary facies and intertonguing in the Upper Cretaceous of the Book Cliffs, UtahColorado: Geological Society of America Bulletin, v. 66, p. 177-201. 